University of Nebraska - Lincoln

DigitalCommons@University of Nebraska - Lincoln

$1-2013$

Connecting with Volunteers: Memorable Messages and Volunteer Identification

Sarah Steimel

Weber State University, ssteimel@gmail.com

Follow this and additional works at: https://digitalcommons.unl.edu/commstudiespapers

Part of the Nonprofit Administration and Management Commons, and the Organizational Communication Commons

Steimel, Sarah, "Connecting with Volunteers: Memorable Messages and Volunteer Identification" (2013). Papers in Communication Studies. 38.

https://digitalcommons.unl.edu/commstudiespapers/38

This Article is brought to you for free and open access by the Communication Studies, Department of at DigitalCommons@University of Nebraska - Lincoln. It has been accepted for inclusion in Papers in Communication Studies by an authorized administrator of DigitalCommons@University of Nebraska - Lincoln. 
Published in Communication Research Reports 30:1 (January-March 2013), pp. 12-21; doi: 10.1080/08824096.2012.746220

Copyright (C) 2013 Eastern Communication Association; published by Routledge/Taylor \& Francis Group. Used by permission.

\title{
Connecting with Volunteers: Memorable Messages and Volunteer Identification
}

\author{
Sarah Steimel \\ Sarah Steimel (PhD, University of Nebraska-Lincoln, 2011) is an Assistant Professor in the \\ Department of Communication at Weber State University. \\ Correspondence: Sarah Steimel, Department of Communication, Weber State University, \\ 1407 University Circle, Ogden, UT 84403; email ssteimel@gmail.com
}

\begin{abstract}
Many of the 1.8 million registered nonprofit organizations in the United States rely on the services of volunteers to be able to connect with and meaningfully serve their communities. However, volunteers are less likely to receive formal socialization and training than paid employees. Thus, this study employs the concept of memorable messages as a way for exploring the ways in which messages received by volunteers from a variety of organizational sources may affect their volunteer identification with the nonprofit organization they serve. Three results emerged from the data, including: (a) sources of memorable messages in volunteer organizations; (b) types of memorable messages in volunteer organizations; and (c) a significant relationship between memorable message type and level of volunteer identification. Implications for connecting with volunteers and for future research are explored.
\end{abstract}

Keywords: memorable messages, organizational identification, volunteers

$F_{c}$ rom his review of organizational identification literature, Cheney (1982) concludes that individuals experience organizational identification as feelings of similarity, belonging, and membership to a group or organization. Individuals identify with organizations to the extent that they feel similar to other members, they feel a sense of belonging, and they consider themselves to be members (Bullis \& Bach, 1989; Mael \& Tetrick, 1992). Research on organizational identification has found that it has a significant positive impact on employee and organiza- 
tional well-being (see Ashforth \& Mael, 1989; Scott et al., 1999).

Unfortunately, current studies of organizational identification have almost entirely focused on full-time, paid, permanent employees of organizations (Ashcraft \& Kedrowicz, 2002). Yet more than 1.8 million officially registered organizations in the United States are non-profit organizations (O'Neill, 2002). For organizations in the nonprofit sector, the altruistic act of volunteering is essential to their success, enabling them to "sustain current services and expand both the quantity and diversity of services without exhausting the agency's budget" (Cnaan \& Goldberg-Glen, 1991, p. 272). Studies of why volunteers choose to volunteer have reported mixed results (see Briggs, Peterson, \& Gregory, 2010). In fact, a number of different variables that prompt volunteering, including: individual variables, such as a self-efficacy or altruism (Martinez \& McMullin, 2004); situational variables, such as time and money (Lenkowsky, 2004); and societal variables, including social networks, religion, and family (Eckstein, 2001; Hustinx \& Lammertyn, 2003) have been identified as significant. Whatever the reason volunteers arrive at the organization, Isbell, Pfiester and McDonald (2007) found that "volunteers who identify with the organization are more likely to commit to future volunteering and demonstrate more positive sentiments towards the organization" (p. 1).

Volunteer identification is therefore critical to the success of the organizations that utilize volunteers because without tangible rewards like pay or benefits, volunteer identification, or that sense of similarity, belonging, loyalty and membership to an organization, plays a significant role in the volunteers' motivation to begin and continue volunteering (Laverie \& McDonald, 2007). Despite this, volunteers typically receive less formal organizational socialization and acculturation than traditional employees (Haski-Leventhal \& Bargal, 2008; Kramer, 2008). Thus, volunteers may be less likely to identify with their organizations than paid employees. Alternatively, volunteers may be more likely than paid employees to rely on informal methods of organizational socialization like memorable messages to establish their identification with the organization for which they work.

Knapp et al. (1981) described memorable messages as meaningful units of communication that affect behavior and guide sense-making processes. According to Barge and Schlueter (2004), memorable messages received informally by new employees from sources like coworkers and immediate superiors influence newcomer socialization and perceived organizational identification. Volunteer identification, however, has yet to be examined through the lens of memorable messages.

Since Stohl (1986) found that, in the for-profit context, memorable messages do influence organizational identification and socialization, the memorable message approach to volunteer organizational identification is important in that it may help organizations understand how volunteers are being socialized in the absence of the formal training programs typically provided to paid employees. Thus, the current study will examine the types of memorable messages received by volunteers in the nonprofit sector, the sources of those messages, and their relationship those messages have with volunteer organizational identification. 
This line of reasoning prompts three research questions:

$R Q 1$ : From whom do volunteers in non-profit organizations receive memorable messages in the organizational context?

$R Q 2$ : What is the content of the memorable messages received by volunteers in non-profit organizations?

$R Q$ 3: Do variations in memorable message content explain the differences in volunteer identification with their non-profit organizations?

\section{Method}

\section{Participants}

A sample of people who had volunteered with an organization within the past three years (or were currently still volunteering) was obtained using a network sample of students, faculty and staff at a four-year public university in a Great Plains state. To be considered for the study, the participant had to be at least 19 years old and had to have volunteered or been volunteering for at least a month in the last three years. Participants were allowed to self-define what "volunteered for a least a month" meant to them, but this language was used to discourage people who only volunteered once at an organization from participating. Further, the three year standard was used to capture both those who were still currently volunteering and those who may have chosen to stop volunteering for any number of reasons. Over the course of the study, 103 people participated. Participant age varied from 19 to 41 (with a median of 20 years). Approximately $67 \%$ of the participants were female and $33 \%$ of the participants were male. Further, approximately $86 \%$ of participants described themselves as White/Non-Hispanic, $8 \%$ of participants described themselves as Asian and/or Pacific Islander, $3 \%$ described themselves as Hispanic and 2\% described themselves as Black/ African/African-American.

\section{Measurement}

This study employed a field-descriptive methodology utilizing a self-administered survey (Barge and Schlueter, 2004). The following concepts were of interest.

\section{Context and Content of Memorable Messages}

Participants were asked to describe in detail a memorable message that made an impact on their volunteering when they first entered their non-profit organization. A short letter attached to the start of the survey used Stohl's (1986) description to define a memorable message as "a piece of advice" or "some words of wisdom" received by the individual. Two examples regarding work as a family and personal-work life separation were included in the letter. After reading the cover letter, participants then recalled and wrote a memorable message received that made an impact on their volunteering when they first entered their non-profit organization. Second, after describing the memorable message, they indicated from whom they had received the memorable message from a list of four choices: 
(1) another volunteer; (2) a paid employee (but not a boss or manager) of the volunteer organization; (3) a boss, manager, volunteer coordinator, or other superior and (4) other. If the participant indicated other, he or she was asked to provide the source of the memorable message. Participants were then allowed to recall additional significant memorable messages that made an impact on their volunteering when they first entered their non-profit organization. In all, the 103 respondents listed 213 memorable messages from their volunteer experiences.

Using the method outlined by Barge and Schlueter (2004), a coder content-analyzed the participant's responses. This coder was given all of the memorable messages recalled $(n=213)$ by the subjects. The coder independently clustered the memorable messages into categories using an inductive method (Taylor \& Trujillo, 2001). Third, the coder met with the primary researcher and discussed the categories that he/she had developed. A master category system was established for types of memorable messages received by volunteers. The researcher then provided two coders with this finalized list of seven message types along with explicit definitions for each category. Using those master code lists, these two coders categorized the messages. Using Cohen's Kappa, the reliability coefficient for the open-ended memorable message coding was 0.82 . The coders then met and resolved any discrepancies.

\section{Organizational Identification}

Organizational Identification was measured using a ten-item scale developed from Mael and Ashforth (1992). The scale's language was adapted to explicitly refer to the organization the individual volunteered for. Previous studies have demonstrated this is a reliable scale, with alpha coefficients ranging from 0.81 to 0.89 (Ashforth, 1997). Items are measured on a 1 to 5 likert-type scale with 1 indicating "strongly disagree" and 5 indicating "strongly agree." Example items include "The organization I volunteer(ed) for's successes are my successes" and "When someone criticizes the organization I volunteer(ed) for, it feels like a personal insult." Scores across the ten-items were added to create a composite organizational identification score, with higher scores indicating higher levels of organizational identification. For these participants, the scores ranged from 18 to 41 with a mean of 27.12 and standard deviation of 4.32 .

\section{Results}

$R Q$ 1: From whom do non-profit volunteers receive memorable messages in the organizational context?

In order to answer the first research question, frequencies were run on the reported sources of volunteer memorable messages $(n=213)$. See specific frequencies in Table 1 below. Further, a one-sample Chi-Square test was run to determine if the messages came equally from each of the reported sources. They did not $\left(x^{2}=76.56, p<.000\right)$. According to volunteers, messages came most frequently from the person they reported to in the volunteer organization (boss, manager 
Table 1. Source of Memorable Messages

\begin{tabular}{lrr}
\hline Message Source & Frequency & Percent of Total \\
\hline 1. Nonprofit Organization Boss/Volunteer Coordinator & 103 & $50.4 \%$ \\
2. Another Paid Employee of Nonprofit Organization & 37 & $17.4 \%$ \\
3. Another Volunteer in the Nonprofit Organization & 36 & $17 \%$ \\
4. Client Served by Volunteer in Nonprofit Organization & 23 & $10.8 \%$ \\
5. Community Member Not in Nonprofit Organization & 5 & $2.3 \%$ \\
6. Other & 2 & $0.9 \%$ \\
\hline
\end{tabular}

or volunteer coordinator). Messages then were sent by other paid employees of the nonprofit organization and other volunteers in the organization, followed by clients served by the organization and community members not involved in the nonprofit organization.

$R Q 2:$ What is the content of the memorable messages received by volunteers in nonprofit organizations?

Next, in order to answer the second research question, messages were sorted into message type categories as described in the method section above. The following content categories for memorable messages were derived from the open-ended memorable message accounts described by participants $(n=213)$. Examples of each theme and their percentage of the total number of messages can be found in Table 2. Themes are listed in descending order of frequency. Further, a one-sample Chi-Square test was run to determine if the messages fell equally into each of the reported types. They did not $\left(\chi^{2}=22.13, p<.002\right)$.

RQ3: Do variations in memorable message content explain the differences in volunteer identification with their non-profit organizations?

Finally, a one-way ANOVA was run to determine if differences in volunteer identification could be explained, in part, by the different types of memorable messages received by the volunteers in this study. ANOVA revealed $(F(7,95)=5.466, p<$ 0.000 ) that there were significant differences in the level of volunteer identification reported by volunteers who had received different types of memorable messages during the initial days of their volunteer experience. Post hoc analyses (Tukey) indicated that volunteers whose most memorable message focused on rules and regulations $(M=32.53)$ had a statistically significantly $(p<0.05)$ lower mean volunteer identification with their nonprofit organization than volunteers who received any other type of memorable message [significance, gratitude, competence, personal advice, benefits to volunteer or family]. Furthermore, volunteers whose most memorable message focused on the significance of the volunteer work $(M=44.29)$ had a statistically significantly $(p<0.05)$ higher mean volunteer identification than volunteers whose most memorable message was one of gratitude $(M=39.31)$, competence $(M=39.32)$ or rules $(M=32.53)$. None of the rest of the types of memorable messages produced statistically significant differences among volunteer identification. See Table 3 below for a summary of these results. 
Table 2. Content of Memorable Messages

\begin{tabular}{|c|c|c|c|}
\hline Theme & Frequency & $\begin{array}{l}\text { Percent } \\
\text { of total }\end{array}$ & Example \\
\hline $\begin{array}{l}\text { 1. Significance } \\
\text { These messages emphasize } \\
\text { how important/meaningful } \\
\text { the volunteer work is. }\end{array}$ & 42 & $19.8 \%$ & $\begin{array}{l}\text { "We have to believe that we are } \\
\text { making a difference. Because look } \\
\text { around, each day that is exactly } \\
\text { what you are doing." }\end{array}$ \\
\hline $\begin{array}{l}\text { 2. Gratitude } \\
\text { These messages thank the } \\
\text { person for volunteering, } \\
\text { explicitly or implicitly. }\end{array}$ & 32 & $15.0 \%$ & $\begin{array}{l}\text { "It's so great kids are still } \\
\text { volunteering these days. Thanks for } \\
\text { sharing your time!" }\end{array}$ \\
\hline $\begin{array}{l}\text { 3. Praising Competence } \\
\text { These messages emphasize } \\
\text { that the volunteer is } \\
\text { doing a good job. }\end{array}$ & 32 & $15.0 \%$ & $\begin{array}{l}\text { "I was told that I did a wonderful } \\
\text { job and I was a great asset to } \\
\text { making the project successful." }\end{array}$ \\
\hline $\begin{array}{l}\text { 4. Personal Advice } \\
\text { These messages offer personal } \\
\text { advice (or "life lessons") to } \\
\text { the volunteer about his } \\
\text { or her life. }\end{array}$ & 30 & $14 \%$ & $\begin{array}{l}\text { "Even if others think what you're } \\
\text { doing is wrong, stand up for what } \\
\text { you believe in and fight for it and } \\
\text { you'll be rewarded." }\end{array}$ \\
\hline $\begin{array}{l}\text { 5. Benefits } \\
\text { These messages emphasize the } \\
\text { benefits (tangible and intangible) } \\
\text { of volunteering to the } \\
\text { volunteer him/herself. }\end{array}$ & 28 & $13.2 \%$ & $\begin{array}{l}\text { "Not only will your experience help } \\
\text { others, but also yourself in reaching } \\
\text { your own leadership potential." }\end{array}$ \\
\hline $\begin{array}{l}\text { 6. Defining Rules } \\
\text { These messages describe rules } \\
\text { and regulations or establish } \\
\text { behavioral expectations } \\
\text { for the volunteers. }\end{array}$ & 26 & $12 \%$ & $\begin{array}{l}\text { "I was told I could come and go as I } \\
\text { please and was reminded to always } \\
\text { fill in my hours sheet." }\end{array}$ \\
\hline $\begin{array}{l}\text { 7. Family } \\
\text { These messages emphasize a } \\
\text { sense of family or team at } \\
\text { the nonprofit organization } \\
\text { and frequently offer support } \\
\text { or help from the } \\
\text { family/team. }\end{array}$ & 15 & $7 \%$ & $\begin{array}{l}\text { "It's like a family here. Just ask us } \\
\text { any question you have. We'd be } \\
\text { glad to help." }\end{array}$ \\
\hline 8. Other & 7 & $3 \%$ & \\
\hline
\end{tabular}

Table 3. ANOVA Comparison of Message Type and Volunteer Identification

\begin{tabular}{llll}
\hline Theme & $\mathrm{M}$ & $\mathrm{F}$ & $p$ \\
\hline 1. Significance & $44.29_{\mathrm{a}}$ & 5.466 & $<0.001$ \\
2. Gratitude & $39.31_{\mathrm{b}}$ & & \\
3. Praising Competence & $39.32_{\mathrm{b}}$ & & \\
4. Personal Advice & $40.63_{\mathrm{a}, \mathrm{b}}$ & & \\
5. Benefits & $41.50_{\mathrm{a}, \mathrm{b}}$ & & \\
6. Defining Rules & $32.54_{\mathrm{c}}$ & & \\
7. Family & $38.58_{\mathrm{a}, \mathrm{b}}$ & & \\
\hline
\end{tabular}

*Pairs of means with different subscripts differ significantly at the .05 level 


\section{Discussion}

\section{Volunteer Identification and Memorable Messages}

This study sought to identify the types of memorable messages received by volunteers in the nonprofit sector, the sources of those messages, and the relationship those messages have with volunteer organizational identification. The participants revealed 213 memorable messages that fell into seven categories: significance, gratitude, competence, personal advice, benefits to volunteer, rules, or family. Those messages were typically received from five sources, including: nonprofit organization boss/volunteer coordinator, paid employee of the nonprofit organization, another volunteer in the organization, a client, and a community member. There was a statistically significant relationship between message type and level of volunteer identification each participant reported with their nonprofit organization.

The messages most frequently reported by volunteers were different in nature than the messages Barge and Schlueter (2004) found that employees reported receiving when they started a new job in a new organization. While for-profit organizational employees frequently reported receiving messages surrounding "fitting into" existing organizational patterns (p. 249), volunteers' memorable messages most frequently focused on the significance of the volunteer work for others, including clients and the community. While professional behavior expectations and work rules may be able to take precedence with employees who are paid to be there, this study revealed that messages focused on rules/procedures were related to a lower reported volunteer identification score than any other message type. As a result, the most effective tactics for socializing a group of individuals who are there voluntarily may be significantly different than those tactics best suited for the employeremployee relationship.

Specifically, this study reveals that memorable messages about the significance or meaningfulness of the volunteer work are associated with statistically higher levels of volunteer identification than other types of messages (those of gratitude, competence, and rules). Interestingly, the social significance of the for-profit company was absent from Barge and Schlueter's (2004) list of most frequently received memorable messages by paid organizational employees. Though it might seem apparent that many people would want to work for a meaningful organization, presumably a paid employee might justify working for a company that they do not see as socially significant because it is "just a paycheck." However, volunteers (excepting those few who are legally required to volunteer) rarely have such an alternative rationale. As such, volunteer socialization programs may do well to focus on the mission and impact of the nonprofit organization as a way to increase the identification of (and decrease the turnover of) volunteers. These messages of significance may be particularly important for nonprofit organizations, particularly when volunteers may be unaware of the ways that their volunteer efforts (filing paperwork, folding clothes or otherwise) fit into the "bigger" and "significant" mission of what a nonprofit organization is attempting to accomplish. 
Further, this study indicates that memorable messages about rules and regulations in an organization are associated with statistically lower levels of volunteer identification than all other types of messages. Though the reason why rules and regulations are associated with lower identification is beyond the scope of this study, it is possible that if the primary socialization messages employees receive in their jobs are related to professional behavior expectations and rules/procedures (as Barge and Schlueter find), the focus on rules and procedures in a space where the individual chooses to be after (or instead of) paid employment may be unwelcome. This may create paradoxes for the nonprofit agency. While many nonprofits, especially who employ volunteers in direct client service positions, have reasonable, and at times important, reasons for wanting to stress rules and procedures with volunteers, it appears that such messages mayrelate to decreased identification (which relates to decreased intent to return). This potentially leaves agencies with a difficult choice - less training/rules or fewer volunteers?

\section{Limitations}

This study may be affected by two types of positivity bias. First, Barge and Schlueter (2004) report that individuals might be more prone to report positive memorable messages than negative ones. Second, individuals who chose to participate in the study might be more likely to have had a positive volunteer experience than those who chose not to participate in the study. Though I defined memorable messages as both positive and negative in my instructions to participants and I allowed participants to participate who had previously (but stopped) volunteering, future research should ask participants explicitly to recount a negative memorable message received.

Second, though this study reveals interesting associations between memorable message type and volunteer identification, this study does not determine causality. Though it is certainly possible that different message types cause volunteers to have different levels of identification with non-profit organizations, it is also possible that volunteers who are highly-identified with a non-profit organization are more likely to recall messages about how significant the work is than volunteers who have low identification.

\section{Future Research}

Despite these limitations, this study has potential for future research extensions. First, given the differences in how different types of messages are associated with different levels of volunteer identification, future projects should continue to investigate the relationship to determine whether different messages also predict or cause increased/decreased volunteer identification. Second, this project extends memorable message research to actors in organizations other than paid employees. Future research should extend the memorable message framework to other non-paid organizational stakeholders. For instance, Aron and Sharkey (1996) explain that often towns have both religious and secular homeless shelters, and they argue that future research should focus on whether and why aid recipients 
might prefer one shelter over another. Those decisions could potentially be influenced by the memorable messages that those in need of help receive when they walk through the door. Ultimately, by extending organizational memorable message research to parties other than paid employees, a much richer picture of the interaction between organizational stakeholders will emerge.

By continuing scholarship along these lines, researchers should be better able to understand how volunteers are socialized into their volunteer organizations through memorable messages and the way(s) in which memorable messages may affect their identification with that organization.

\section{References}

Aron, L. Y., \& Sharkey, P. T. (1996). The 1996 national survey of homeless assistance providers and clients. Urban Institute. Posted March 12, 2002. http://www.urban.org/url. cfm?ID=410496

Ashcraft, K. L., \& Kedrowicz, A. (2002). Self-direction or social support? Nonprofit empowerment and the tacit employment contract of organizational communication studies. Communication Monographs, 69(1), 88.

Ashforth, B. E. (1997). Petty tyranny in organizations: A preliminary examination of antecedents and consequences. Canadian Journal of Administrative Sciences, 14, 126-140.

Ashforth, B. E., \& Mael, F. (1989). Social identity theory and the organization. Academy of Management Review, 14, 20-39.

Barge, J. K., \& Schlueter, D. W. (2004). Memorable messages and newcomer socialization. Western Journal of Communication, 68(3), 233-256.

Briggs, E., Peterson, M., \& Gregory, G. (2010). Toward a better understanding of volunteering for nonprofit organizations: Explaining volunteers' pro-social attitudes. Journal of Macromarketing, 30, 61-76.

Bullis, C., \& Bach, B. W. (1989). Socalization turning points: An examination of change in organizational identification. Western Journal of Communication, 53, 273-293.

Cheney, G. (1982). Organizational identification as process and product A field study. Unpublished master's thesis, Purdue University.

Cnaan, R. A., \& Goldberg-Glen, R. S. (1991). Measuring motivation to volunteer in human services. Journal of Applied Science, 27(3), 269-284.

Eckstein, S. (2001). Community as gift-giving: Collectivistic roots of volunteerism. American Sociological Review, 66, 829-851.

Haski-Leventhal, D., \& Bargal, D. (2008). The volunteer stages and transitions model: Organizational socialization of volunteers. Human Relations, 61(1), 67-102.

Hooghe, M. (2003). Participation in voluntary associations and value indicators: The effect of current and previous participation experiences. Nonprofit and Voluntary Sector Quarterly, 32, 47-69.

Hustinx, L., \& Lammertyn, F. (2003). Collective and reflexive styles of volunteering: A sociological modernization perspective. Voluntas: International Journal of Voluntary and Nonprofit Organizations, 14, 167-187.

Isbell, M., Pfiester, R., \& McDonald, A. (2007). Increasing participation through identification: A case study of the American Red Cross of Central Texas. A paper presented at the annual meeting of the National Communication Association, Chicago, IL. 
Knapp, M. L., Stohl, C., \& Reardon, K. K. (1981). “Memorable" messages. Journal of Communication, 31, 27-41.

Kramer, M. (2008). A study of voluntary organizational membership: The assimilation process in a community choir. Paper presented at the annual meeting of the National Communication Association, San Diego, CA.

Laverie, D. A., \& McDonald, R. E. (2007). Volunteer dedication: Understanding the role of identity importance on participation frequency. Journal of Macromarketing, 27(3), 274-288.

Lenkowsky, L. (2004). What motivates Americans to volunteer? Chronicle of Philanthropy, 16,39 .

Mael, F. A., \& Ashforth, B. E. (1992). Alumni and their alma mater: A partial test of the reformulated model of organizational identification. Journal of Organizational Behavior, 13(2), 103-123.

Mael, F. A., \& Tetrick, L. E. (1992). Identifying organizational identification. Educational and Psychological Measurement, 52(4) 813-824.

Martinez, T. A., \& McMullin, S. L. (2004). Factors affecting decisions to volunteer in nongovernmental organizations. Environment and Behavior, 36(1), 112-127.

O'Neill, M. (2002). Nonprofit nation: A new look at the third America. . San Francisco: Jossey-Bass.

Scott, C. R., Connaughton, S. L., Diaz-Saenz, H. R., Maguire, K., Ramirez, R., Richardson, B., et al. (1999). The impacts of communication and multiple identifications on intent to leave: A multimethodological exploration. Management Communication Quarterly, 12, 400-435.

Stohl, C. (1986). The role of memorable messages in the process of organizational socialization. Communication Quarterly, 34(3), 231-249.

Taylor, B. C., \& Trujillo, N. (2001). Qualitative research methods. In F. M. Jablin \& L. L. Putnam (Eds.), The new handbook of organizational communication: Advances in theory, research and methods (pp. 161-194). Thousand Oaks, CA: Sage. 